\title{
点字ブロックを利用した自律移動ロボットの屋外ナビゲーション
}

\author{
吉田智 章* 大矢晃 久*油田信 一*
}

\section{Autonomous Mobile Robot Navigation Using Braille Blocks in Outdoor Environment}

\author{
Tomoaki Yoshida*, Akihisa Ohya* and Shin'ichi Yuta*
}

\begin{abstract}
A mobile robot can use the walls or the pillars to localize itself when it navigates in indoor environment. However, in open space or outdoor environment there are few easy detectable and stable objects that the robot can use. In this paper, we propose a method for the detection of braille blocks, which are originally used for visually handicapped people, for autonomous mobile robot navigation. To recognize the braille block, a CCD camera and a laser fan beam projector are used as sensor to detect uneven surface of the blocks. This paper also present the experimental results of simple navigation using the sensor system.
\end{abstract}

Key Words: Mobile Robot, Braille Block, Laser Range Sensor, Outdoor Navigation

\section{1. はじめに}

自律移動ロボットにとって, 自己位置認識は非常に重要な機 能である，屋内環境においては，ロボットが自己の位置を認識 するために，簡単なセンサによって壁や柱などを容易に検出す ることが可能である。これらの物体は人間にとっても識別しや すいため,これらの物体の記載された環境地図を作成すること は容易であり，したがって信頼性の高いナビゲーションシステ ムが実現できる。一方屋外では, 環境の整備された道路上で車 両を自動走行させる研究はいくつかある $[1] \sim[4]$. しかし, 車道 を走行できない小型の移動ロボットにとって, 簡単なセンサで 安定して検出できる物体は少ないため, 従来の研究では複雑な 画像処理などを利用してロボットの自己位置を計測するものが 多い[5]〜 [9]. しかし，こういったシステムを小型の移動ロボッ 卜に実装するのは，搭載できるハードウェアの制限や処理能力 の制限により難しい，そこで，歩道に敷設されている点字ブロッ クを移動ロボットに利用させることを考えた。点字ブロックは 視覚障害者誘導用の設備であり, 市街地に広く敷設されている. この点字ブロックに沿って走行することによって, 歩道を安全 に移動できる。

本論文では，点字ブロックを用いた移動ロボットのナビゲー ション方法，およびその実装について述べる。また，そのため に開発したセンサシステムとロボットのコントローラについて 説明し，実験によって提案する手法と実装の有効性を検証する.

原稿受付 2002 年 10 月 16 日

*筑波大学

${ }^{*}$ University of Tsukuba

\section{2. 点字 ブロック}

点字ブロックは視覚障害者を誘導するための標識で, 歩道な どの路面に広く設置されている. 本論文で対象とする点字ブロッ クを Fig. 1 に示す，点字ブロックは小さな円形の凸部が格子 状にならんだ警告ブロックと細長い長方形の凸部が平行になら んだ誘導ブロックの 2 種類があり, どちらも標準色が黄色であ るので, 周囲とのコントラストにより弱視の人でも容易に認識 できる．ただし色については周囲の景観との整合性を配慮して， 標準色以外の色のブロックが使われていることも多い.

点字ブロックは世界各地で利用されているが, サイズと形状 は様々なものがある. 本研究で対象としている点字ブロックは,
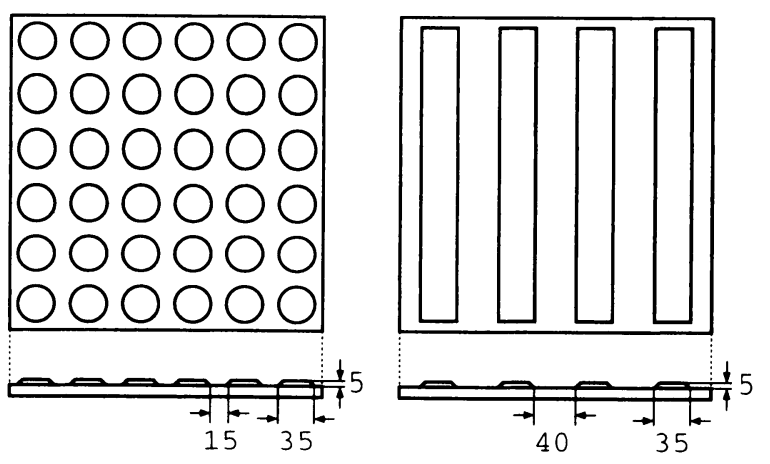

unit: $\mathrm{mm}$

Fig. 1 Two styles of braille block. A dot style block which indicates an endpoint or branch of a path is shown in left side, and a line style block which indicates a path is shown in right side 


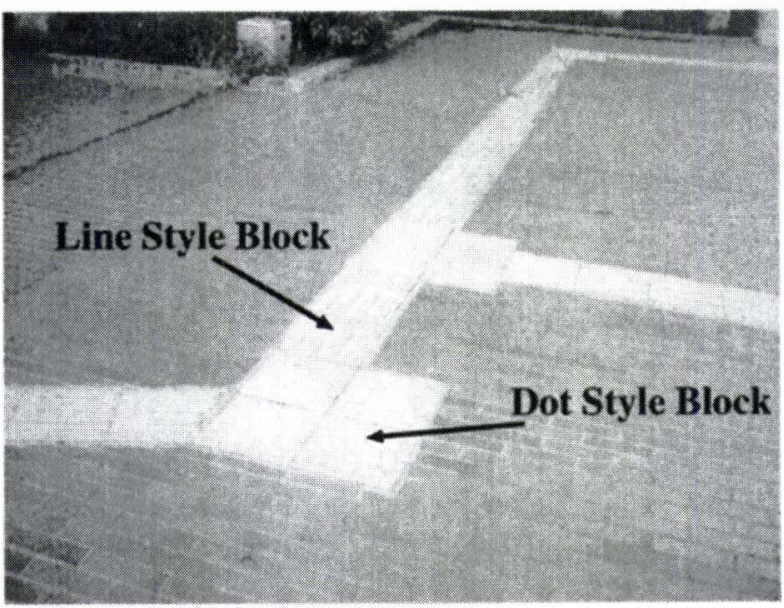

Fig. 2 Example of braille blocks on pedestrian

日本で考案されて国内に広く普及しているものであり，同種の ブロックはオセアニア，東南アジアなどのいくつかの国でも利 用されている。

Fig. 2 に点字ブロックが設置された歩道を示す。誘導ブロッ クは連続して設置されて移動できる経路を表し, 警告ブロック は誘導ブロック列の分岐点や終端, 建物の入口などに設置され て注意を要する場所であることを表す。この情報により，点字 ブロックだけを頼りに歩道を移動することができる。

\section{3. 点字ブロックのナビゲーションへの利用}

ロボットのために整備された環境では, 壁沿い走行やライン トレースは, 移動ロボットがあらかじめ定義された長い経路を 走行するための簡単で有効な手段である．誘導ブロック列を経 路と見なすことで, 屋外環境も混沌としたものではなく整備さ れた環境と見なすことができる.

本研究で提案するナビゲーション方法では, 基本的に移動口 ボットは誘導ブロック列に沿って走行する. 分岐点などの意味の ある場所への到達は警告ブロックを検出することで分かり，そ の後の行動はあらかじめ作成しておいた地図を参照して決定す る。経路が誘導ブロック列によって定義されることや経路長は ブロックの数を数えることで算出できることなどから, 地図は 容易に作成することが可能である。

\section{1 点字ブロックの検出法}

点字ブロックの検出と認識は, 点字ブロックの色を検出する 手法と凹凸を検出する手法が考えられる。点字ブロックの標準 色は弱視の人も容易に見分けられるように黄色になっており標 準色を使うことが推奨されている $[10]$. この場合, カラー画像を 用いて検出することができるが [11], 実際には多くのバリエー ションがあり，景観に気をつかって目立たない色のブロックが 使われることも多々ある．さらに屋外で運用するためには光源 の条件の変化にも対応する必要があり，その実現には困難を伴 う。一方で，点字ブロックの表面の凹凸は高さが $5[\mathrm{~mm}]$ であ り，この凹凸を検出できればロバスト性の高い検出法が実現可 能である、また，点字ブロックの種別は凹凹の差異によって容 易に判別できる.

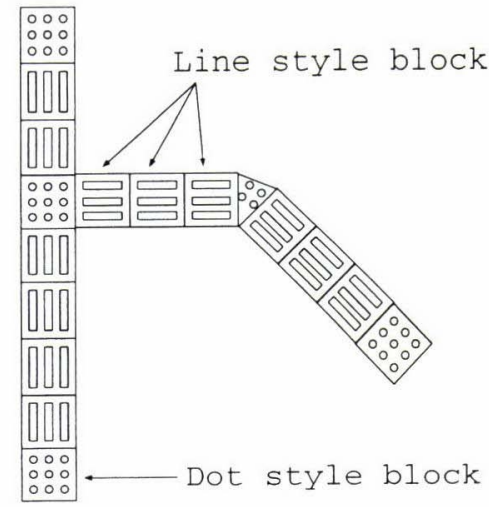

Fig. 3 Example pattern of the braille block

そこで本研究では, 凹凸を検出する手法を用いることとし, そ のために赤外線レーザとカメラを利用したセンサシステムを構 築した．ただし点字ブロックの表面の凹凸は高さが $5[\mathrm{~mm}]$ と 小さく, 移動ロボットがこの凹凸を検出するには土夫を要する. 本センサでは, レーザスリット光を地面に対して, 非常に浅い 角度 (約 5 度) で照射し, その反射光を視線が地面に対して深 い角度になるように高い位置に設置したカメラで観察する。こ の構成で地面の小さな山凸を精度よく検出でき, 点字ブロック の種別, 位置, 向いている方向が認識可能となる.

\section{2 点字ブロックの地図}

ロボットは点字ブロックの配置に関する地図を持ち, その地 図上での現在地と, 指定された目的地までの経路を, たどるべ き点字ブロック列として計画する, その計画に従い, 誘導ブロッ クに沿って走ることで目的地に到達する.ロボットがどの誘導ブ ロック列上にいるかを把握していれば, 誘導ブロック列中の正 確な位置を知る必要はなく，警告ブロックを発見することで誘 導ブロック列の終端を知るとともに地図上の自己位置の確認が できる，そのため，グローバルな座標系を基準とした位置べー スの詳細な環境地図は必要ない。これらを考慮すると, 環境地 四には分岐点もしくは曲がり角をノード，経路をアークとした グラフと, 各ノードで経路がどのように接続しているかの情報 が記載されていればよい。ただし本研究では，ロボットが誘導 ブロック列の終端付近に到達したときに, 速度を落として終端 を見逃さないようにするために，誘導ブロック列の長さも補助 的に記録し，信頼性の向上を目指した。地図の例として, Fig. 3 に点字ブロックの配置を, Fig. 4 に対応する地図を示す.

点字ブロックが存在しない，あるいは途切れている区間につ いてのナビゲーションは本研究で扱う範囲外であるが, 屋外で 長距離のナビゲーションを行う際には必要となる場面もあると 考えられる。この場合, その区間については別のセンサシステ ムや環境地図が必要となる.

\section{3 点字ブロックを用いたナビゲーション}

ロボットは走行時に現在位置と目的地が与えられ, 環境地図 を用いて点字ブロックをどのようにたどって移動するかを計画 する，移動計画は，誘導ブロックに沿った走行と，警告ブロッ クのある曲がり角や分岐点における次の誘導ブロック列への移 動の組み合わせとなる。ロボットは,この移動計画に従って誘 


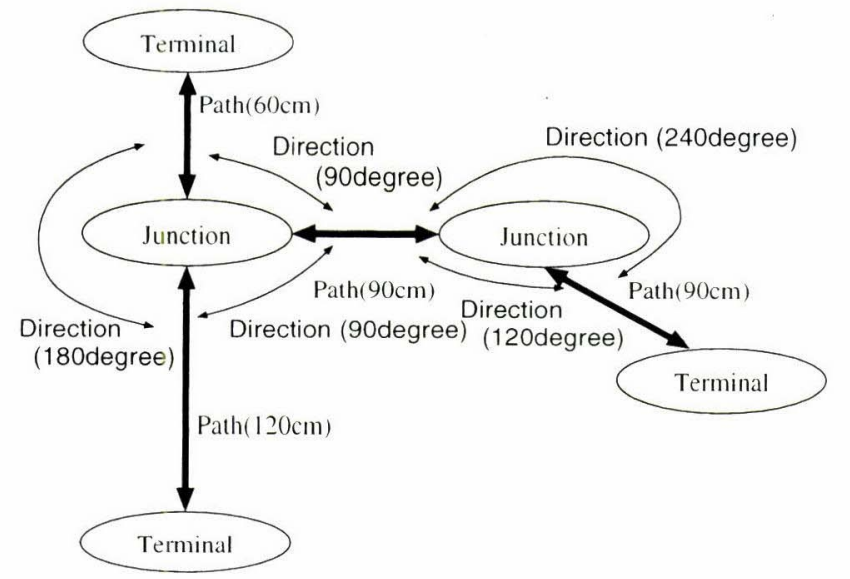

Fig. 4 Corresponding environmental map to the block pattern shown in Fig. 3

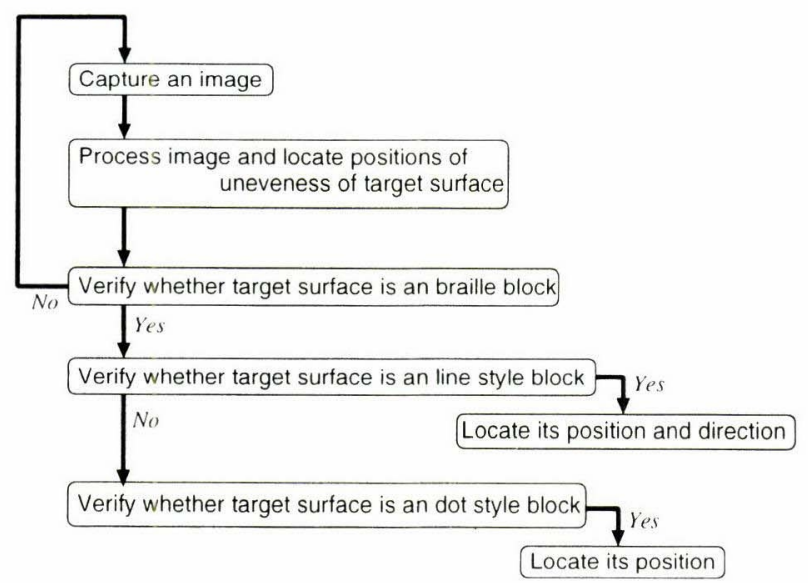

Fig. 5 Braille block sensor process flow

導ブロック列に沿って走行し，分岐点で目的地へと続いている 次の誘導ブロック列へと乗り換えることを繰り返し，最終的に 目的地へと移動する.

\section{4. 点字ブロックをガイドとした走行}

点字ブロックは，路面の凹凸をセンサで検出することによっ て認識する. Fig. 5 に点字ブロック検出処理の流れを示す。ま ず，七ンサにより検出した凹凸の数，間隔，ばらつきから，そ れが点字ブロックによるものなのか，また点字ブロックによる ものであれば 2 種類の内どちらのブロックなのかを判断する. 誘導ブロックと判断したときには列の向きと位置を測定し， ロ ボットは検出した誘導ブロック列に沿って走行する。一方，警 告ブロックを検出したときは, 検出位置を分岐点か終端である とみなし, 地図を参照して次の行動を決定する。

\section{1 センサ}

赤外線レーザのスリット投光器と干渉フィル夕を取り付けた カメラを用いて，三角測量により路面の凹凸を測定する、ロボッ トの車輪が点字ブロック上を継続的に走行するとスリップが非 常に大きくなり，オドメトリによる走行距離推定に大きな䛊差 を含んでしまう，そのためロボットは点字ブロックの右側を走

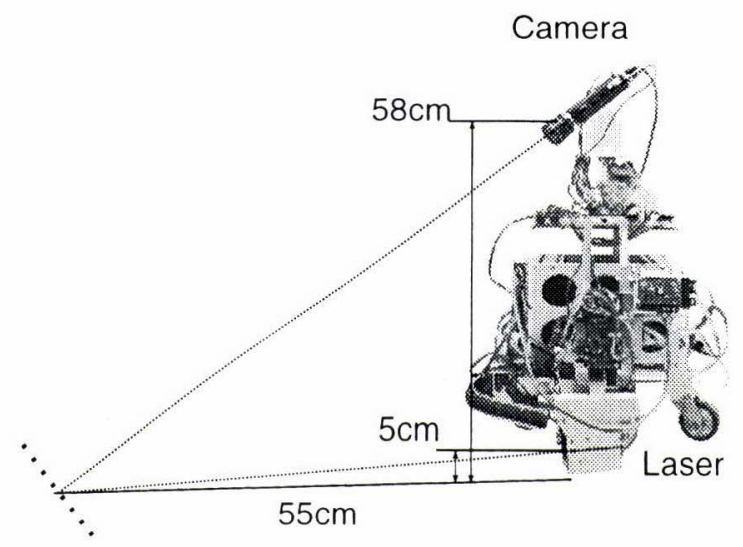

Fig. 6 Configuration of the laser source and the camera

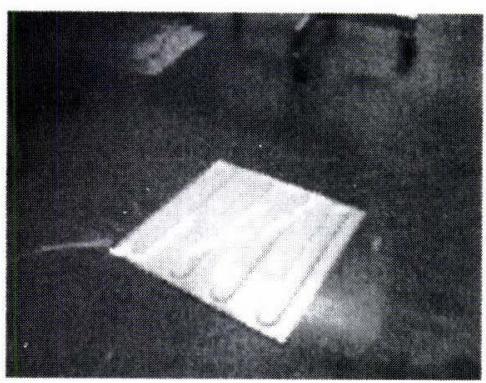

Fig. 7 Image from the camera(without filter) aimed at the line style block

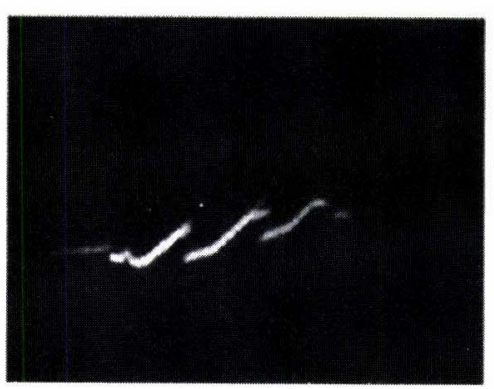

Fig. 8 Image from the camera with filter aimed at the line style block

行し，センサはロボットの左前方約 $50[\mathrm{~cm}]$ の路面を計測する こととした，左前方を斜めに計測する配置は，レーザスリット 光と誘導ブロックの向いている方向との角度を大きく取れるた め，後述する誘導ブロックの向きの計算にも有利である.

点字ブロックの凸部の高さが $5[\mathrm{~mm}]$ であり，これを検出でき る解像度を確保するためにレーザ投光器とカメラの位置関係を 検討した. Fig. 6 にその配置を示す. 焦点距離 $8.5[\mathrm{~mm}]$ のレン ズを取り付けた NTSC 信号を出力するカメラを用いて $50[\mathrm{~cm}]$ 先の点字ブロックを認識する十分な精度を確保するには, カメ ラの高さを $50[\mathrm{~cm}]$ 程度に, レーザの照射角を 10 度以下にする 必要がある. 実装したシステムではカメラを $58[\mathrm{~cm}]$ の高さに取 り付け, レーザ投光器を高さ $5[\mathrm{~cm}]$ から左前方 $55[\mathrm{~cm}]$ の位置 に照射角 5 度で照射することにした，屋内に設置した誘導ブロッ クを干渉フィルタを外したカメラで撮影した画像を Fig. 7 に, 干涉フィル夕を取り付けたカメラで取得した画像を Fig. 8 に示 


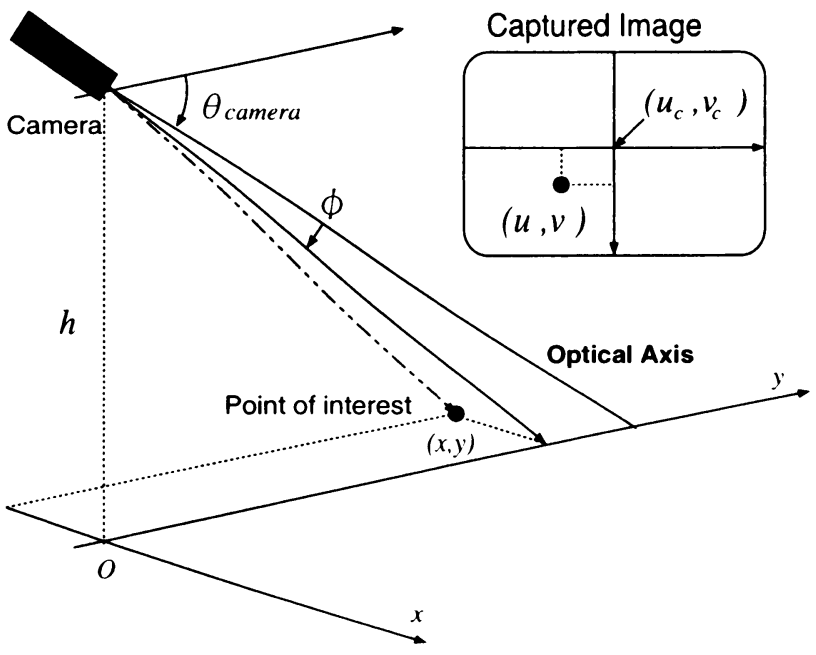

Fig. 9 Parameters for coodinate conversion

す. 白い線が路面に照射されたレーザの反射光であり, 路面の 小さな高低差により反射光は画面上で上下方向に動き, 路面が 高いところでは下にずれて映っていることが分かる．点字ブロッ クの突起部ではこのずれが大きくなるので，ずれの大きい部分 が突起部の候補となる．投光するレーザの波長と同じ $780[\mathrm{~nm}]$ の干涉フィルタをカメラに取り付けて使用しているため, 屋内 など赤外光源がほとんどない環境では，レーザの反射光以外は ほとんど現れない。また, 屋外でも直射日光下でなければレー ザの反射光がその他の部分に対して十分に明るくなり，簡単な 2 值化処理で反射光だけを切り出すことができる．いくつかの 条件下での実験では, 薄量りの場合程度によるが 3 割から 7 割, 晴れていた場合の影の中ならば 7 割, 直射日光下では誤検出が 多発して使用できない結果となった。また，曇りの場合や夕方 以降であればほほ 10 割レーザ反射光を検出できた。

得られた画像は, 画像中での各縦ラインについて下から上に 走査して輝度の闒值 $T h_{\text {intensity }}$ を超える部分を探し, 最初に 閾值を超えた画素群のうち最も輝度の高い画素を画像上のレー ザ反射点とする，次に各縦ラインごとに検出されたレーザ反射 点列の画素を横に探索し, 縦方向に途切れて不連続となってい る部分を探す. 見つかった不連続点を, 点字ブロックの突起部 の候補とする。この画素の座標に対して，画像は地平面を撮影 したものと仮定した以下の座標变換を施すことにより, 環境中 での実際の突起の位置を求める.

座標変換に必要なパラメー夕は, カメラの俯角 $\theta_{\text {camera }}$, 高 さ $h$, 焦点距離 $f, \mathrm{CCD}$ 上でのピクセル間隔 $\Delta v, \Delta u$ であり, カメラから見た実環境中での座標系を左右方向に $x$, 奥行き方 向に $y$ を取るとする (Fig. 9). また, 画像上で光学中心の画 素の座標を $u_{c}, u_{c}$ とし, 注目する画素の座標を $u, v$ とする と, 実環境中地平面上での座標は次式で求めることができる。

$$
\begin{aligned}
& x=\frac{h \Delta_{u}\left(u-u_{c}\right)}{f \sin \left(\theta_{\text {camera }}+\phi\right)} \\
& y=\frac{h}{\tan \left(\theta_{\text {camera }}+\phi\right)}
\end{aligned}
$$

ただし， $\phi$ はカメラの中心軸から注目画素に対応する方向への
晃久油田信一

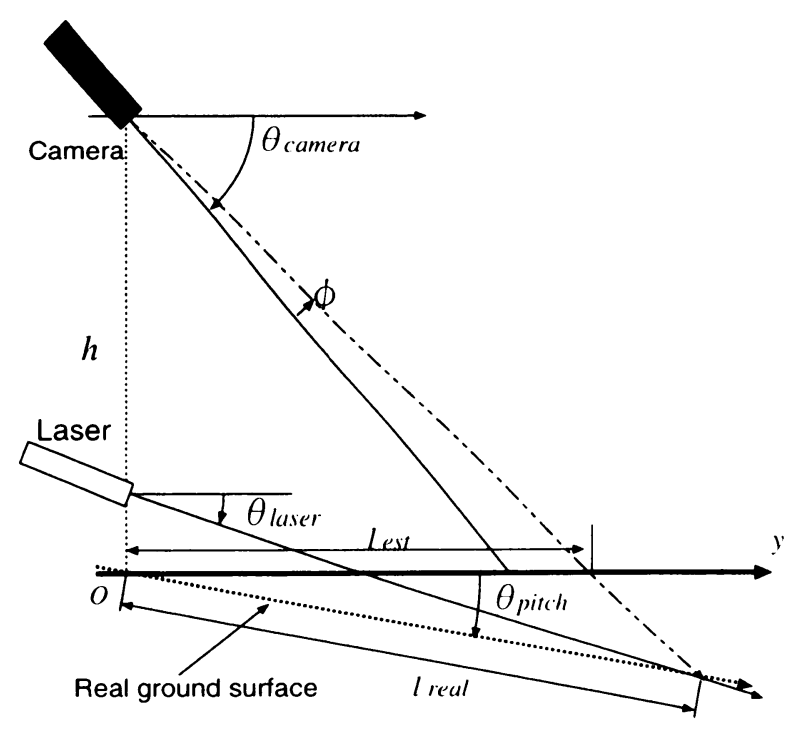

Fig. 10 A model for error estimation

俯角であり，

$$
\phi=\arctan \left(\frac{\Delta_{v}\left(v-v_{c}\right)}{f}\right)
$$

である。

この手法ではロボットの前後方向の振動により仮定した平面 が実際と異なってしまい, 求まる反射点の位置の誤差が生じる 可能性がある。そこで, どの程度の誤差が含まれる可能性があ るかを検討した。

Fig. 10 に，ロボットのピッチ方向の回転 $\left(\theta_{\text {pitch }}\right)$ を考慮し たモデルを示す。このモデルにおけるレーザ反射点までの推定 値 $l_{\text {est }}$ と実際の值 $l_{\text {real }}$ との差は以下の式で表せる.

$$
\begin{aligned}
l_{\text {real }}-l_{\text {est }}= & \frac{x\left(\tan \theta_{\text {laser }}-\tan \theta_{\text {pitch }}\right)}{\cos \theta_{\text {pitch }}\left(\tan \theta_{\text {laser }}-\tan \theta_{\text {pitch }}\right)} \\
& -h \tan \left(\frac{\pi}{2}-\theta_{\text {camera }}-\phi\right)
\end{aligned}
$$

本システムでは使用したカメラの上下の視野角は \pm 20 度 $\theta_{\text {camera }}$ は 39 度である。この条件では，ロボットが前方に傾い た場合，最大で $\theta_{\text {pitch }}=3.5$ 度の傾きまでレーザ反射光を視野 内に納めることができる。このとき，誤差は $1[\mathrm{~cm}]$ 程となる. また，ロボットが後方に傾いたときは最大で 3.6 度の傾きまで 視野内に納めることができるが，反射点が遠いとレーザの反射 光が弱くなり，画像上で認識できなくなるため, 屋外での実験 では $l_{\text {real }}$ が $80[\mathrm{~cm}]$ を超えるとほとんど検出されなかった。 こ のときの $\theta_{\text {pitch }}$ は 1.4 度なので, 式 (4) より誤差は約 $4[\mathrm{~cm}]$ となる。

以上より，ロボットが前後に傾いた場合においてもレーザ光 を認識できる範囲ではナビゲーションに十分な精度でブロック の位置が求まることが確認できた。 また，ロボットが大きく傾 いた場合は，レーザ光の反射点がカメラの視野外に出てしまう ため, 誤差の大きな出力は発生しにくいことも分かった. 


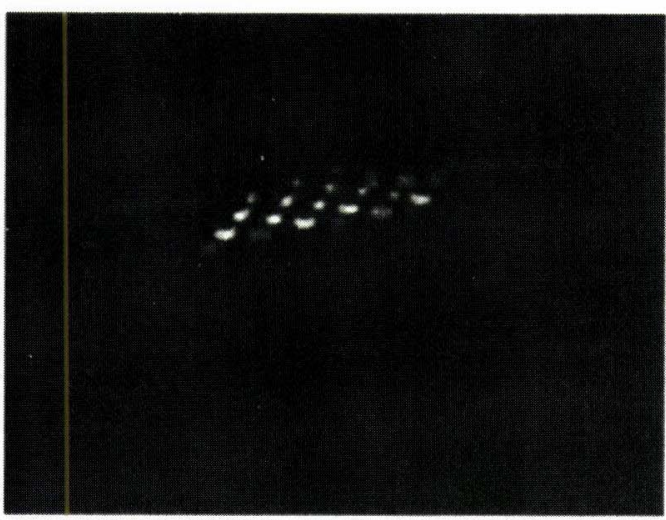

Fig. 11 A captured image of a dot style block

\section{2 ブロックの認識と種別の判断}

以上の手続きで得られた突起部の候補点に関する実環境中の 位置を, 誘導ブロックと警告ブロックそれぞれの特徵と比較し, ブロック種別の認識を行う。

誘導ブロックは表面に 4 本の長方形の突起部が並んでいる. そのため以下の条件を満たすときに誘導ブロックであると判断 する.

・突起部の候補点の間隔が実際の誘導ブロックの突起部の間 隔と同じかそれより大きい

- 1 回の計測で得られるいくつかの候補点の間隔が，その平 均值に対して $\pm T h_{\text {interval }} \%$ 以内の值である

突起部の候補点は，ブロックの突起部とレーザスリット光の交 点であるため, その間隔がブロックの突起部の間隔より狭くな ることはない.ほとんどの場合は，レーザ光が斜めに交差する ために突起部の候補点の間隔が実際のブロックの突起部の間隔 より広くなる.これらの条件に加えて, 誘導ブロックの向きを 計算するために，最低三つの突起部が検出されたときに誘導ブ ロックと判断する。

誘導ブロックが完全に視野内にあれば理想的には突起部は 4 個だけ見つかるはずであるが，点字ブロックの周囲に存在しう る凹凸を検出して 4 個よりも多くなる場合がある。そこで, 多 く検出した場合には隣り合う 3 個か 4 個の突起を組み合わせ, 誘導ブロックの条件に合致するかを検証する。

次に, 以下の条件で警告ブロックの判定を行う.

・誘導ブロックではない

・多数の候補点がある

- 候補点の距離が互いに一定距離 $T h_{M i n D i s t}$ 以上離れている 警告ブロックは表面に多数の凸部を持つため，センサでは多数 の突起が検出される.Fig. 11 は，その典型的な一例であるが， この場合 9 個の突起が検出される。実験によると, 通常 8 個か ら 11 個の突起が検出されることが分かった，警告ブロックの突 起間隔は誘導ブロックによるものより狭いが，点字ブロックの ない路面で検出する可能性のあるランダムなノイズの間隔より は十分に広い。そこで, 誘導ブロックの突起の数である 4 個よ り多い6 個以上の突起を検出し, それぞれの突起の間隔が一定 值 Th MinDist 以上であった場合には警告ブロックと判断する. なお上記以外の場合は，ノイズと判断して無視する。

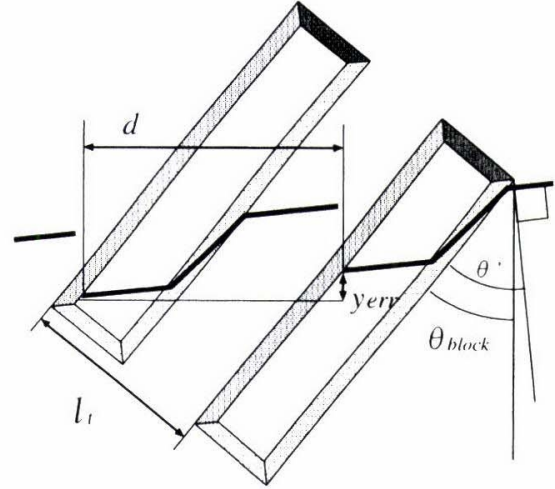

Fig. 12 The line style block on which laser fan beam projected

\section{3 誘導ブロックの向きの算出}

検出した突起の間隔と実際の誘導ブロックの突起部の間隔か ら, 以下の式でレーザスリット光に対する誘導ブロックの向き を計算する。

$$
\theta^{\prime}=\arccos \frac{l_{t}}{d}
$$

ただし、レーザ光に対する誘導ブロックの向きを $\theta^{\prime}$ ，検出した 突起の間隔を $d$, 実際の誘導ブロックの突起の間隔を $l_{t}$ とする. この方法では実際には角度の符号は分からないが，七ンサは口 ボットの左前方に向けて取り付けて角度をバイアスすることに より0度付近にならないように使用していれば，符号を仮定で きる。

レーザは浅い角度で路面に照射するため，ロボットのロール 方向の摇れに敏感に反応して照射位置が変動する。そのため， $\theta^{\prime}$ はそのままではセンサに対する誘導ブロックの向きとして扱え ないが，ロボットに対するレーザの傾きは二つの突起の位置か ら求めることができるので，結局次の式でロボットに対する誘 導ブロックの向きが求まる(Fig. 12$)$.

$$
\theta_{\text {block }}=\arccos \frac{l_{t}}{d}-\arctan \frac{y_{e r r}}{d}
$$

\section{4 誘導ブロック沿い走行}

誘導ブロックの位置と向きが認識できれば，ロボットが存在 している局所的な環境で，誘導ブロックに沿って走るための経 路計画ができる。

Fig. 13 において, 点 $P$ は検出した誘導ブロックの突起部の うち左端の突起部の端の点, $\theta_{\text {block }}$ は突起部の間隔から計算し たブロックの向き, 直線 $l$ は点 $P$ と $\theta_{\text {block }}$ によって決まる誘 導ブロックの左端の突起部が乗っている直線である。さらにこ の直線にロボットの中心 $O$ から垂線 $O Q$ を引く.

誘導ブロックの位置と向きが安定して精度良く認識できる理 想的な条件下では, 直線 $m$ に示すような誘導ブロックから一 定距離 $Q R$ の位置を平行に走る経路上を走行すればよい。し かし実際には認識結果には䛊差が含まれることを考慮し，理想 条件下での経路と認識時のロボットの位置と向きの中間となる 直線 $n$ を目標直線とし, 複数回の認識と直線追従の結果とし て最終的に理想条件下の経路に近い経路を走行できるようにし た. 直線 $n$ は $\overrightarrow{O S}=t \overrightarrow{O R}$ となる点 $S$ を通りロボットに対して 


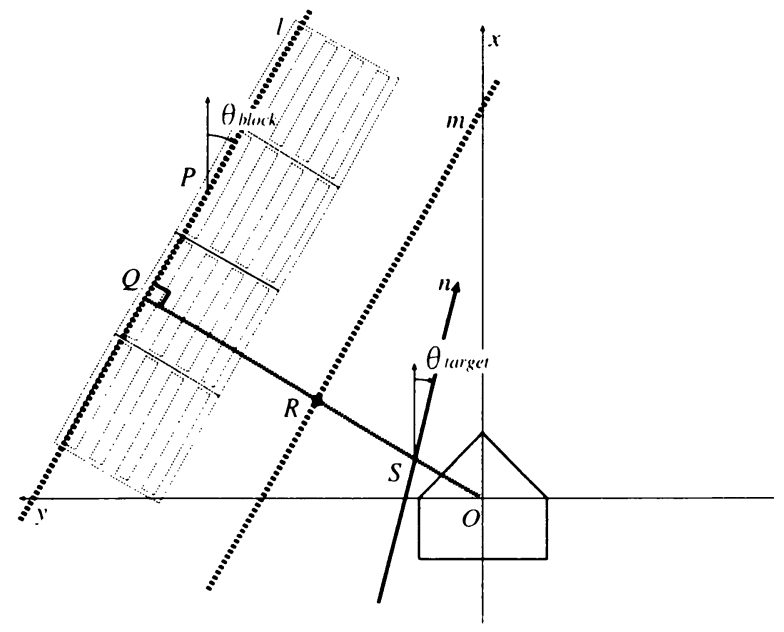

Fig. 13 Configuration for target line generation

$\theta_{\text {target }}=s \theta_{\text {block }}$ となる $\theta_{\text {target }}$ を向いている直線とした．た だし， $0<t<1,0<s<1$ であり，実験時にはこれらの值を 経験的に $t=0.3$ と $s=0.5$ とした.このようにして生成した 経路への追従を計測のたびに繰り返すことで誘導ブロック沿い 走行を実現した。

\section{5. 屋外ナビゲーションのための対策}

屋外ではロボットの摇れ, 外乱光の影響, 路面の凹凸など様々 な問題が発生し，七ンサによる点字ブロックの検出頻度や精度 は一定しない。このような状況下で安定して走行するための対 策を検討した。

点字ブロックの検出頻度が大きく変化する状況でロボットが 一定速度で走行すると, 十分に点字ブロックを検出できずに見 逃してしまう状況が発生する。しかし，それを防ぐために低速 度で走行させると長距離の移動に非常に時間がかかってしまう. そこで, 走行時に点字ブロックの検出頻度を監視し, 状況に応じ て走行速度を変化させることにした。また，連続して検出に失 敗した場合，ロボットがブロック列から逸脱している可能性が ありブロック列に復帰できなくなるおそれがあるため, Th $h_{\text {Lost }}$ 回連続して検出できなかった場合は最後に検出できた場所まで 引き返すことにした。

Fig. 14 に簡単なナビゲーション行動の例を示す．まず誘導 ブロックに沿って走行中に十分な頻度でブロックを検出できて いれば少しずつ加速し（1）, 路面の凹凸やゴミなどにより検出 頻度が落ちると減速しながら走行する。そして経路の終端に近 づくと確実に警告ブロックを検出するために減速する（2）．終 端を検出したら（3）, 次の誘導ブロック列に移動する (4).

ブロック列の終端もしくは曲がり角における次の誘導ブロッ ク列への移動は, 移動先の誘導ブロック列がどこにあるかで行 動を変える必要がある.ここでは，Fig.15に示す三つの場合 に分類して考える．移動先が左にある場合は，設置されている 鳘告ブロックに並ぶ分前進し, その後左旋回して次の経路へと 移動する，移動先が正面にある場合は，設置されている警告ブ

\footnotetext{
†画像処理自体は 1 フレーム当たり 0.2 [ms]（Pentium MMX $233 \mathrm{MHz}$ ) で完了する.
}

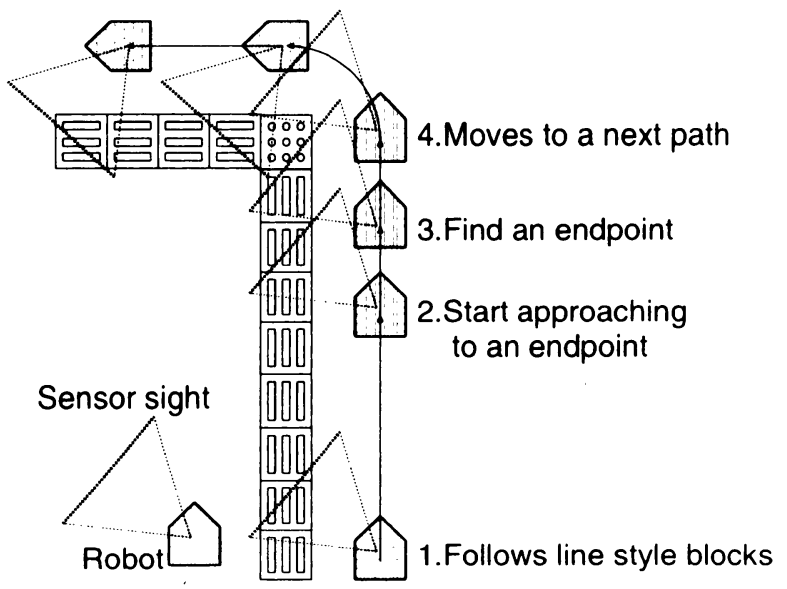

Fig. 14 A behavior sequence of navigation

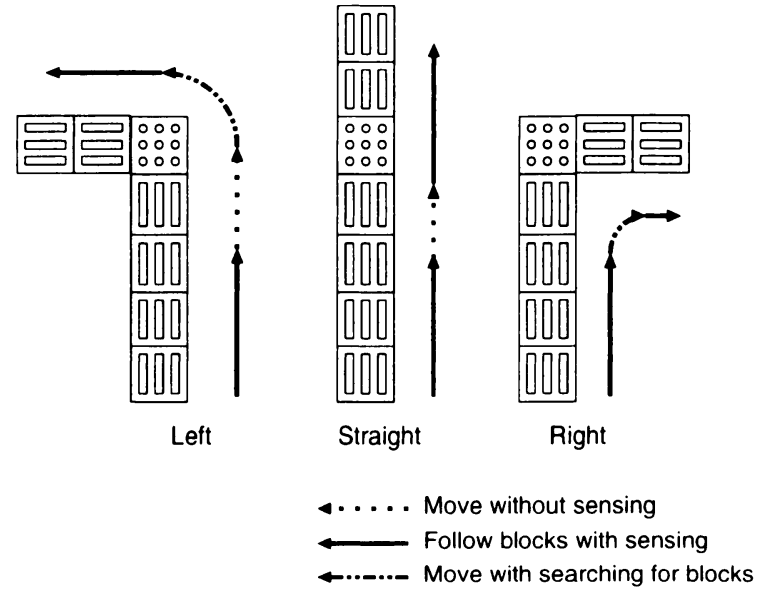

Fig. 15 Types of movement at junctions

ロックの分直進した後，前方の誘導ブロックを探す．移動先が 右にある場合，警告ブロックを発見した位置から右旋回し，移 動先のブロックの方向付近で誘導ブロックを探す.

\section{6. 実験}

\section{1 実験システム}

実装は，筆者らの研究室で開発している自律移動ロボット「山 彦」[12] に行った。山彦は $55 \mathrm{~cm}$ の高さに取り付けたカメラを 除くと $40[\mathrm{~cm}] \quad(\mathrm{W})$ X $40[\mathrm{~cm}]$ (D) X $50[\mathrm{~cm}]$ (H) で，カ メラを含めた高さは $70[\mathrm{~cm}]$ である.カメラとレーザは左前方 に向けて取り付け, 約 $50[\mathrm{~cm}]$ 前方の点字ブロックを検出する. カメラの出力は, ビデオキャプチャカードを用いて取り込み 処理する. 使用したビデオキャプチャカードの仕様により, カ メラの出力は解像度 $320 \times 240$ で平均毎秒 5 フレームのスピー ドで取り込む。この取り込みにかかる時間がセンサ全体の処理 速度の大きな制限要因になっており，現状のシステム上ではそ の他画像処理などにかかる時間は取り込みにかかる時間に比べ ると無視できるほど短い†。

ロボットはビデオキャプチャカードを装備したノート型 PC から，走行制御モジュールにコマンドを送ることによって制御 


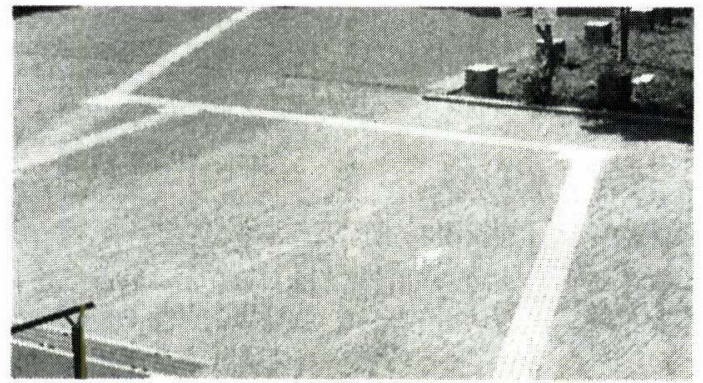

Fig. 16 Experimental environment for navigation task

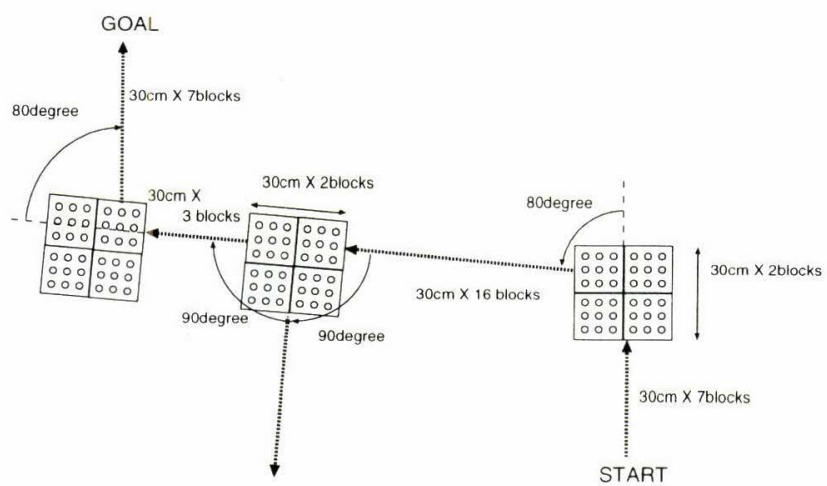

Fig. 17 The map used in the outdoor experiment

する.ノート型 PCではカメラ画像を取り込み, 処理し，ロボッ トの挙動を決定する。その後，シリアルポートに接続した走行 制御モジュールと通信してロボットを走行させる.

この実験で使用した点字ブロック検出およびナビゲーション パラメータは以下の通りである。

$$
l_{t}: 74[\mathrm{~mm}]
$$

Thintensity: $40 \%$

ThMinDist: $6[\mathrm{~mm}]$

Thinterval: $10 \%$

$T h_{\text {Lost }}: 15$ 回

\section{2 屋外ナビゲーション}

Fig. 16 に示寸環境で，簡単なナビゲーション実験を行った. この環境には，警告ブロックのある分岐と曲がり角があり，誘 導ブロック列でつながっている。この環境でのブロックの地図

をFig. 17 に示す.ロボットは 9 〜 $25[\mathrm{~cm} / \mathrm{s}]$ でおよそ $15[\mathrm{~m}]$ を 約 90 [秒] かけて走行した.

この実験ではロボットは以下の行動を順に実行した。

(1) Fig. 16 の左下の地点から走行を開始.

(2) 誘導ブロックに沿って 7 ブロック分 $(2.1[\mathrm{~m}])$ 走行.

(3) 終端付近で減速し, 警告ブロックを探しながら誘導ブロッ クに沿って走行.

（4）発見した警告ブロックの横まで直進.

（5）次の経路に乗るために左旋回しながら誘導ブロックを探す。

（6）発見した誘導ブロックに沿って 16 ブロック分 $(4.8[\mathrm{~m}])$ 走行.

（7）終端付近で減速し，警告ブロックを探しながら誘導ブロッ クに沿って走行.

（8）発見した警告ブロックの横まで直進.

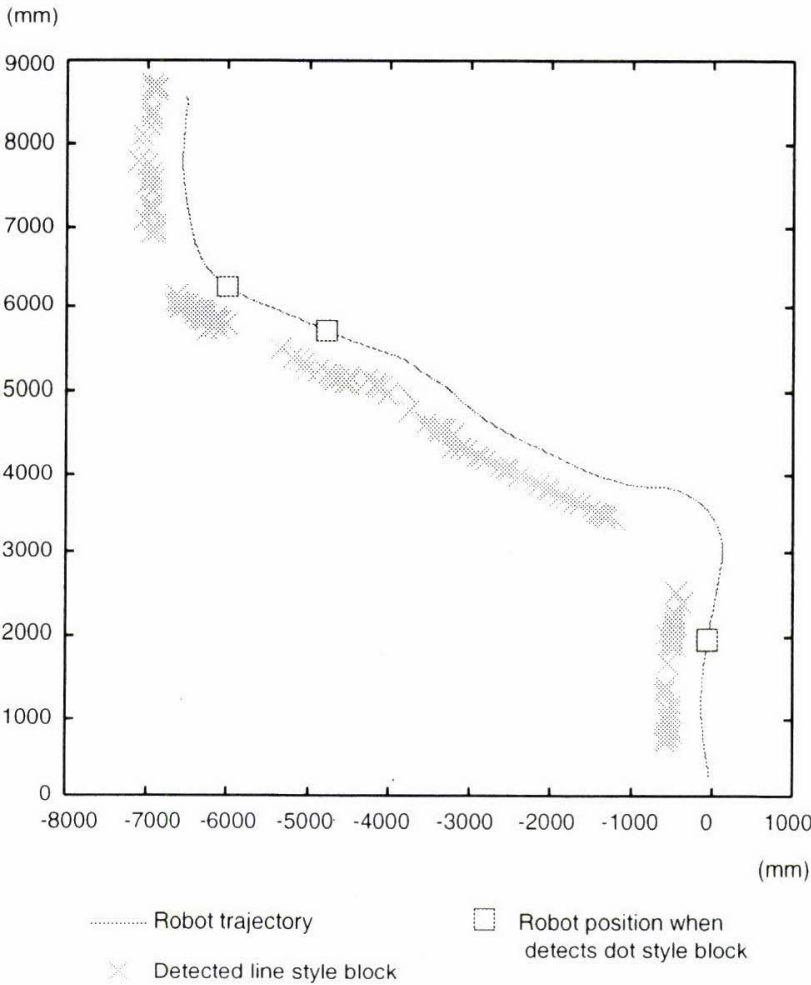

Fig. 18 Detected line style block positions and robot position in the outdoor navigation task

（9）次の経路に乗るために直進しながら誘導ブロックを探す.

(10) 発見した誘導ブロックに沿って 3 ブロック分 $(0.9[\mathrm{~m}])$ 走行.

（11）終端付近で減速し，警告ブロックを探しながら誘導ブロッ クに沿って走行.

（12）次の経路に乗るために右旋回しながら誘導ブロックを探す.

(13) 発見した誘導ブロックに沿って 7 ブロック分 $(2.1[\mathrm{~m}])$ 走行.

以上の行動におけるロボットのオドメトリによる推定自己位 置と, 検出したブロックの位置の記録を Fig. 18 に示す. 眓中

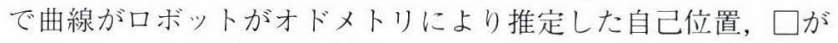
警告ブロックを発見したときのロボットの位置，×が検出した 誘導ブロックの位置を示している．ブロックが正しく検出され, ナビゲーションが成功していることが分かる。

ロボットはハードウェアに制限された一定時間間隔（約 $200[\mathrm{~ms}])$ で点字ブロックの検出を試みるため, ロボットの走 行速度によって検出間隔は変化する。 また, カメラの角度と違 い, レーザの照射角は浅いため, 照射する位置はロボットの摇 れに影響されて動く、そのため, 検出するブロックは摇れに応 じて近くのブロックであったり少し離れたブロックであったり と変動する.Fig. 19 に Fig. 18 の走行記録の一部を拡大したも のを示す. Fig. 19 では検出した誘導ブロックの位置と検出時の ロボットの位置を点線で結んでプロットしてある。誘導ブロッ クが検出された位置は前後にばらついているが，すべて誘導ブ ロック列上のどこかを検出しており，誘導ブロックの位置が正 しく計測できていることが分かる.

様々な環境での実験の結果，屋内では直射日光がなければ蛍 光灯など他の証明条件によらずほぼ $100 \%$ 成功することが分かっ 


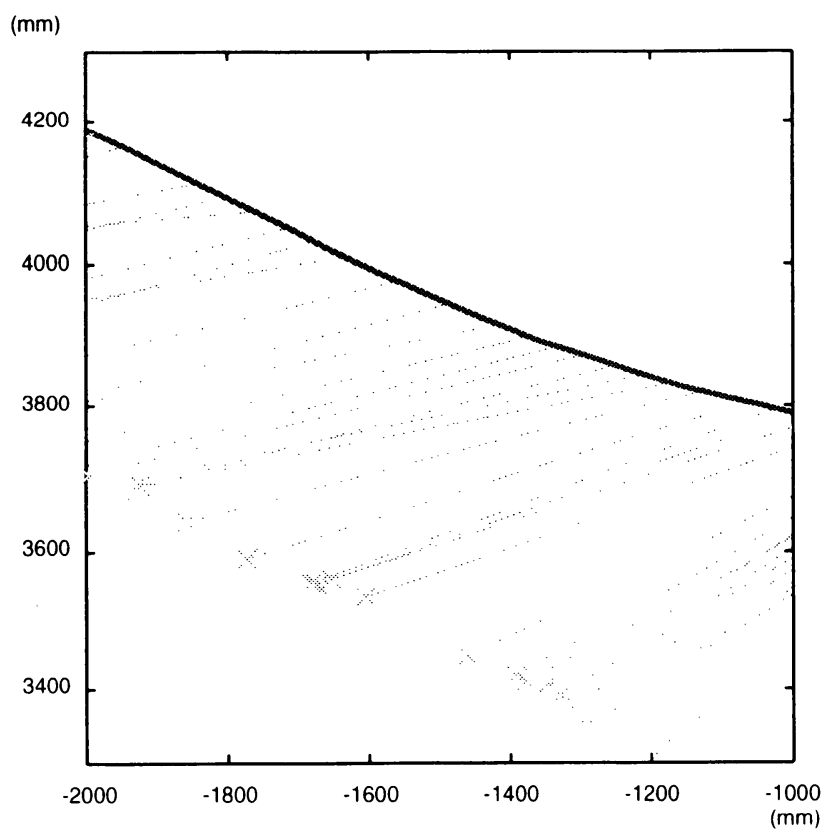

Robot trajectory

Detected line style block

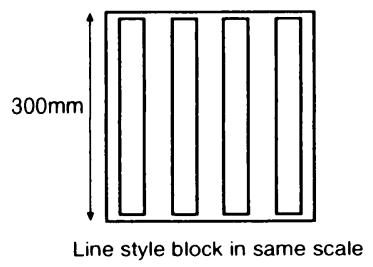

Fig. 19 Detected line style block positions and robot position in the outdoor navigation task (zoomed)

た。また，屋外では地面の凹凹によりロボットが摇れてレーザ 光がブロックに当たらない状況が数秒続くと, 本来の経路から のずれが大きくなり，ブロック列に戻れなくなる場合や，路面 の溝にはまって動けなくなる場合があり，直射日光がない環境 での成功率は $70 \%$ から $80 \%$ 程度であった。

\section{7. ま と め}

本論文では，レーザとカメラを用いた点字ブロックの検出方 法と，実装したセンサシステム，およびこれを用いた自律移動 ロボットのナビゲーションの実現について述べた。本センサシ ステムを用いることにより，ロボットは誘導ブロックに沿った 走行と，分岐点等における警告ブロックの検出が可能になった. 点字ブロックは, 本論文で対象とした形状以外にも突起の数, 大 きさ, 間隔が違うものも存在するが, そういったブロックも原 理的には検出パラメータの変更で対応できる，また，本論文で 提案する手法はブロックの形状を認識するため, ブロックの色 にかかわらず適用可能である。
環境地図に基づくナビゲーションシステムを構築し, 屋外に おける実験を行った結果, ロボットは正しく走行し, 本システ 么の有効性を確認することができた。本論文では屋外での実験 結果のみを示したが，より整った環境である屋内においても本 手法が有効であることは言うまでもない.

直射日光下で動作させるには，ロボットにひさし状の物を取 り付け，レーザ光が照射される地面に影を作るようにすれば対 応可能と思われるが，実験と検証は今後の課題である。また， より検出のロバスト性を上げるには，レーザ光検出の閾值を動 的に決定する，ブロックのレーザ光が照射されている部分をパ ターンマッチングで検出するなどの処理を導入する必要がある. これらの検討も今後の課題である.

\section{参 考 文 献}

[1] C. Thorpe, M.H. Hebert, K. Kanade and S.A. Shafer: "Vision and Navigation for the Carnegie-Mellon Navlab," Transactions on Pattern Analysis and Machine Intelligence, vol.10, no.3, pp.362-373, 1988.

[2] T.M. Jochem, D.A. Pomerleau and C.E. Thorpe: "VisionBased Neural Network Road and Intersection Detection and Traversal," Proc. IEEE Conf. Intelligent Robots and Systems, vol.3, pp.344-349, 1995 .

[3] D. Kuan and U.K. Sharma: "Model Based Geometric Reasoning for Autonomous Road Following," Proc. IEEE Int'l Conf. Robotics and Automation, pp.416-423, 1987.

[4] S. Tsugawa, T. Yatabe, T. Hirose and S. Matsumoto: "An Automobile with Artificial Intelligence," Proc. Sixth Int'l Joint Conf. Artificial Intelligence, pp.893-895, 1979.

[ 5 ] S. Kotani, K. Kaneko, T. Shinoda and H. Mori: "Mobile robot Navigation Based on Vision and DGPS Information," International Conference on Robotics and Automation, pp.2524-2529, 1998.

[6] V. Graefe: "Dynamic Vision System for Autonomous Mobile Robots," Proc. IEEE Int'l Conf. Intelligent Robots and Systems, pp.12-23, 1989.

[ 7 ] M.A. Turk, D.G. Morgenthaler, K.D. Gremban and M. Marra "VITS-A Vision System for Autonomous Land Vehicle Navigation," IEEE Trans. Pattern Analysis and Machine Intelligence, vol.10, no.3, pp.342-361, 1998.

[ 8 ] A.M. Waxman, J.J. LeMoigne, L.S. Davis, B. Srinivasan, T.R. Kushner, E. Liang and T. Siddalingaiah: "A Visual Navigation System for Autonomous Land Vehicles." IEEE Trans. Robotics and Automation, vol.3, no.2, pp.124-141, 1987

[9] S. Tachi and K. Komoriya: "Guide Dog Robot," International Symposium on Robotics Research, vol.2, pp.333-340, 1985

[10] 全日本視覚障害者協議会: http://www.normanet.ne.jp/\%7ezensi/

[11] H. Mori, K. Kobayashi, N. Ohtuki and S. Kotani: "Color Impression Factor: an Image Understanding Method for Outdoor Mobile Robots," International Conference of Intelligent Robots and Systems, pp.380-387, 1997.

[12] S. Yuta: "Autonomous Self-contained Robot 'Yamabico' and its Controller Architecture," Third Australia National Conference on Robotics, 1990. 


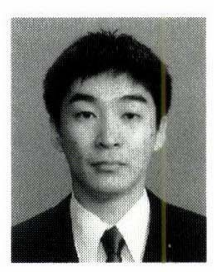

吉田智章 (Tomoaki Yoshida)

1974 年 7 月 6 日生. 1999 年筑波大学大学院工学 研究科博士課程入学, 現在に至る.自律移動ロボッ トの行動制御，ロボット用コントローラなどの研究 に従事.

(日本ロボット学会学生会員)

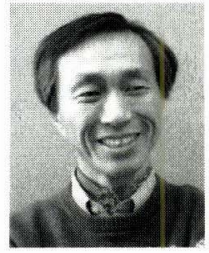

油田信一（Shin'ichi Yuta)

1948 年 3 月 23 日生. 1975 年慶應義塾大学大学院 (電気工学専攻) 修了. 現在, 筑波大学機能工学系教 授、知能移動ロボット，ロボットセンサ，ロボット 用コントローラなどの研究に従事. 自動制御や信号 処理の理論と応用に興味を持つ. 工学博士. IEEE, 計測自動制御学会などの会員.

(日本ロボット学会正会員)

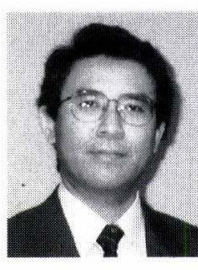

大矢晃久 (Akihisa Ohya)

1965 年 3 月 16 日生. 1992 年慶應義熟大学大学院 理工学研究科後期博士課程 (電気工学専攻) 修了. 同年，筑波大学電子 ·情報工学系助手. 現在，同助 教授. 1995 1997 年米国 Purdue 大学客員研究員. 2000 2003 年科学技術振興事業団さきがけ研究 21 研究者 (兼務)。人間の生活空間で働く移動ロボッ 卜，実環境七ンサ情報処理などに関する研究に従事．博士（工学）。 IEEE, 計測自動制御学会, 日本音響学会, 電子情報通信学会などの 会員. 